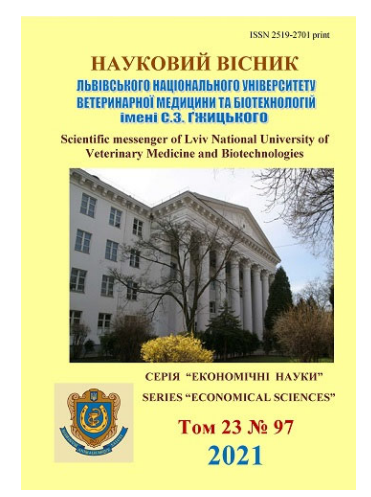

Науковий вісник Дьвівського національного університету
ветеринарної медицини та біотехнологій імені С.3. Гжицького. Серія: Економічні науки

\author{
Scientific Messenger of Lviv National University \\ of Veterinary Medicine and Biotechnologies. \\ Series: Economical Sciences
}

ISSN 2519-2701 print

https://nvlvet.com.ua/index.php/economy

doi: 10.32718/nvlvet-e9703

UDC 330.111.66:331.104:338.431

\title{
Development of social and labor relations in rural areas in terms of integration of the agricultural sector of the agro-industrial complex into the EU structure
}

\author{
O. V. Kopytko, R. V. Seniv, N. V. Denys \\ Stepan Gzhytskyi National University of Veterinary Medicine and Biotechnologies Lviv, Lviv, Ukraine
}

Article info

Received 10.09.2021

Received in revised form 11.10 .2021

Accepted 12.10.2021

Stepan Gzhytskyi National University of Veterinary Medicine and Biotechnologies Lviv,

Pekarska Str., 50, Lviv,

79010, Ukraine.

Tel.: +38-073-496-84-35

E-mail:senivrv@ukr.net
Kopytko, O. V. Seniv, R. V. \& Denys, N. V. (2021). Development of social and labor relations in rural areas in terms of integration of the agricultural sector of the agro-industrial complex into the EU structure. Scientific Messenger of Lviv National University of Veterinary Medicine and Biotechnologies. Series: Economical Sciences, 23(97), 14-18. doi: 10.32718/nvlvet-e9703

Social and labor relations in the process of market environment development in the agricultural sector of the agro-industrial complex are undergoing significant changes. The study of these changes is necessary to identify trends that characterize all the processes associated with the use of labor, increase its productivity and impact on the efficiency of agricultural production. Miscalculations in socio-economic policy result in negative consequences and loss of human capital. One of the peculiarities of the period of Ukraine's integration with the EU in Ukraine is that the state does not regulate the content of social and labor relations, and other regulators, such as social partnership, are not yet working at full capacity. The most serious problems were in social and labor relations directly on agricultural enterprises and especially in farms and households. There is a need for effective state influence, using the opportunities of OTG, on the formation of a national model of social and labor relations and the effective use of labor potential. Further development of social and labor relations should be carried out in the context of Ukraine's integration with the EU, which raises the need to improve socio-economic policy towards the agricultural sector in terms of its transformation and adaptation to European integration structures. It is advisable to determine the main directions and priorities of socio-economic modernization of OTG in the coming years. The main ones are: and popularization of knowledge, including the reform of rural vocational schools, the search for new forms of adult learning, the development of economic, technical and social infrastructure, support for entrepreneurship and non-agricultural activities in rural areas.

Key words: social and labor relations, agricultural sector, labor market, Ukraine's integration into the $E U$, united territorial communities, socio-economic policy, state regulation.

\section{Розвиток соціально-трудових відносин на селі в умовах інтеграції аграрно- го сектору АПК в структури СС}

О. В. Копитко, Р. В. Сенів, Н. В. Денис

Львівський національний університет ветеринарної медицини та біотехнологій імені С. 3. Гжицького, м. Львів, Україна

Соціально-трудові відносини в прочесі розвитку ринкового середовища в аграрному секторі АПК зазнають суттєвих змін. Дослідження ичх змін необхідно для визначення тенденцій, які характеризують всі прочеси, пов'язані з використанням праці, підвищенням ї̈ продуктивності і впливу на ефективність сільськогосподарського виробництва. Прорахунки в соціально-економічній політиці обертаються негативними наслідками і втратою людського капіталу. Одна з особливостей періоду інтеграції Украйни з ЄС в Україні полягає в тому, щуо держава не регламентує змісту соиіально-трудових відносин, а інші регулятори, такі як соиіальне партнерство ще не працюють на повну потужність. Найбільш серйозні проблеми були в соиіально-трудових відносинах безпосередньо на сільгосппідприємствах і особливо у фермерських та господарствах населення. Необхідно ефективний державний вплив, використовуючи можливості ОТГ, на формування національної моделі сочіально-трудових відносин та ефективного вико- 
ристання трудового потенціалу. Подальший розвиток соиіально-трудових відносин повинен здійснюватись в контексті інтеграції Украӥни з СС, щуо висуває необхідність вдосконалення сочіально-економічної політики щзодо аграрного сектора в умовах його трансформації і пристосування до інтеграційних структур Європи. Доцільно визначити основні напрямки і пріоритети соціальноекономічної модернізацї ОТГ в найближчі роки. Головними з них є: популяризація знань, в тому числі реформа сільських профтехучилищ, пошук нових форм навчання дорослих, розвиток економічної, технічної та соціальної інфраструктури, підтримка підприємництва і несільськогосподарської діяльності в сільській місчевості.

Ключові слова: сочіально-трудові відносини, аграрний сектор, ринок праці, інтеграція України в ЄС, об'єднані територіальні громади, соиіально-економічна політика, держане регулювання.

\section{Вступ}

Реформування агропромислового комплексу призвело до суттєвих змін в правових, економічних, соціально-трудових відносинах в аграрній сфері тому на сучасному етапі одним із актуальних питань розвитку цього сектора $є$ стан та подальший розвиток соціально-трудових відносин. Перш за все, це стосується напрямів соціальної політики, функціонування ринку праці та ефективної трудової зайнятості сільського населення, зменшення міграції працездатного сільського населення. Сьогодні особливо важливо вирішення соціально-економічних проблем, підвищення ефективності використання трудового потенціалу аграрної сфери: забезпечення офіційної зайнятості сільського населення, що позитивно вплине на їх пенсійне забезпечення. Актуальні питання формування та реалізації аграрної політики в сфері соціально-економічних соціально-трудових відносин в агропромисловій сфері досліджені в наукових працях вчених: Гіндес О.Г., Герасименко О.О., Гнатишин Л.Б., Грішнова О.А., Колот А. М., Костирко І.Г., Малецька O.I., Прокопишин О.С., Саблук П.Т., Ткачук В. А. та інших. Їхні праці внесли вклад в питань теорії та практики формування і розвитку соціально-трудових відносин в суспільстві.

Meта статmi. Обгрунтування розвитку сфери соціально-економічних відносин в аграрній сфері, в умовах переходу до соціально-ринкової системи господарювання і їх входження в європейський інтеграційний економічний простір, $з$ метою випередження негативних соціально-економічних проявів зумовили вибір теми публікації.

\section{Матеріал і методи досліджень}

В процесі дослідження застосовувалися наукові праці вчених з проблем теорії та практики формування, функціонування та розвитку, соціально-трудових відносин в аграрній сфері, загальнонаукові, аналітичні методи, Інтернет-ресурси, побудовані на використанні діалектичного методу і системного підходу до вивчення економічних процесів, теоретичних положень, що базується на системно-функціональному підході соціально-трудових відносин в умовах ринкових трансформаційних процесів на селі.

\section{Результати та їх обговорення}

Еволюція виробничих відносин на селі за останні 30 років ставить завдання нового осмислення питань теорії та практики формування і розвитку людини i сукупності їі потреб, здібностей, інтересів, життєвих цілей, ефективної реалізації, соціально- економічних передумов і закономірностей формування трудового потенціалу, умов залучення і повного використання всіх можливостей людського фактору, їх впливу на ефективність вітчизняного виробництва, загостренням проблем економічного розвитку взагалі та відтворення трудового потенціалу, як одного з його індикаторів, зокрема. Трансформація виробничих відносин відбувається в контексті того, що Україна зайняла топові місця у світовому аграрному експорті за результатами 2020 року (Mistse Ukrainy u svitovomu..., 2021).

1 місце: соняшникова олія - загальна сума експорту склала 5,3 млрд \$;

1 місце: соняшниковий шрот - 1,1 млрд \$;

2 місце: ріпак - 1 млрд \$;

2 місце: просо - 29 млн \$;

4 місце: кукурудза - 4,9 млрд \$;

4 місце: ячмінь - 877 млн \$;

5 місце: пшениця - 3,6 млрд \$;

7 місце: соя - 690 млн \$.

Разом $з$ тим складовими цього процесу є зубожіння сільського населення, зростання безробіття в усіх іiі формах, трудова міграція, деградація кадрового потенціалу аграрних підприємств. Так, у 2010 р. середньомісячна заробітна плата у сільському господарстві становила 1430 грн, тоді як середня по Україні 2239 грн, у 2017 р. - 5761 грн, при середній заробітній платі в країні 7104 грн (Tkachuk, 2019). Середній рівень зарплат у сільському господарстві України 3 січня до липня зріс на 1 тис. грн. У звітності зазначено, що у січні 2020 року середній рівень зарплати у сільському господарстві, а також лісництві та рибництві становив 8542 грн, тоді як у липні за червень 2020 року люди отримували в середньому 9508 грн. Рекордним за рівнем середньої зарплати на селі був квітень, коли отримували працівники, а керівники платили 10140 грн. Це офіційні показники зарплати, про яку звітують роботодавці. Нагадаємо, найбільше на обліку у службі зайнятості на кінець весни 2020 року було агрономів та тваринників. Про це свідчить статистика, надана у спільному звіті Державної служби зайнятості та Державної служби статистики України (Serednii riven zarplat..., 2021). Виходячи із вищесказаного, слід створити таке економічне середовище, яке б стимулювало впровадження в практику комплексної стратегії формування зайнятості сільського населення та соціально-трудових відносин, з одного боку, і функціонування високоефективного аграрного виробництва - $з$ іншого, що позитивно впливатиме на зайнятість та оплату праці. Соціально-трудові відносини в процесі розвитку ринкового середовища в аграрному секторі АПК зазнають суттєвих 
змін. Дослідження цих змін необхідно для визначення тенденцій, які характеризують всі процеси, пов'язані з використанням праці, підвищенням їі продуктивності i впливу на ефективність сільськогосподарського виробництва.

Щоб забезпечити інтеграцію аграрного сектору в структури СС на сучасній основі, необхідні, перш за все, якість трудового потенціалу працівників, суб'єктів господарювання. Слід відзначити (Kolot \& Herasymenko, 2019), що перетворення, які відбуваються у соціально-трудовій сфері під впливом інформаційно-комунікаційних технологій, мережевих систем, інших ресурсів та інститутів нової економіки, це навіть не радикальні зміни, а повна, всеохоплююча трансформація, стан, коли змінюється все, або майже все, - цінності, мотиваційні настанови, ієрархія, першоджерела розвитку, структура ресурсів, форми та технології взаємодії, форми та масштаби зайнятості, рівень, структура, диференціація доходів; співвідношення (ієрархія) економічного і позаекономічного; форми організації праці тощо.

Тому необхідно створити умови, які дозволили б повну свободу підприємництва, і реалізацію інтересів як держави, бізнесу та найманих працівників. Поряд із соціальним захистом, ринок повинен оцінити індивідуальний працю кожного і забезпечити йому умови відповідно до творчого пошуку i якості праці. Входження України в регульоване ринкове середовище обумовлює необхідність забезпечення мотивації праці в сільському господарстві. Аграрна праця, на відміну від праці взагалі, має свої особливості, що визначають специфіку іiі мотивації. Це пов'язано 3 функціонуванням різних форм власності і господарювання, неоднаковим рівнем механізації основних виробничих процесів, ставленням сільських трудівників до земельної реформи.

Відносини між соціальною державою, суб'єктами підприємництва і свідомими громадянами мають формуватися на основі взаємної відповідальності, що $\epsilon$ своєрідним способом обмеження політичної влади держави і створення цивілізованих рамок підприємницької діяльності та людської поведінки. Це виявляється у прийнятті державою конкретних зобов'язань, спрямованих на забезпечення інтересів громадян, у реальній відповідальності державних органів та посадових осіб за виконання їх обов'язків перед суспільством і громадянами. Соціальна держава закріплює в конституції та гарантує природні права людини, які постійно розширюються, вдосконалюються і їх суворо дотримуються. Водночас підприємства і громадяни в такій державі безумовно виконують встановлені правила, свої обов'язки перед суспільством, державою, іншими людьми, обмежують свою діяльність соціально- етичними нормами (Hrishnova, 2011).

Необхідно відзначити, що соціально-трудові відносини в аграрному виробництві, піддаються багатофакторному впливу - це: форми власності на засоби виробництва, мотивація праці, продуктивність праці, рівень заробітної плати, соціально-психологічні відносини в колективі. Сьогодні склалася парадоксальна ситуація на ринку праці в сільській місцевості - дефіцит трудових ресурсів і наявність безробіття. Низька в
Україні середня заробітна плата сільського населення 3 одного боку, і складні процеси функціонування сільгосппідприємств які забезпечують низькі показники ефективності господарювання, що негативно впливає на забезпечення АПК країни об'єктами інфраструктури - 3 іншого.

Істотним якісним зрушенням у глобальному економічному мисленні сьогодні стало визнання людського ресурсу ключовим серед основних чинників виробництва, а інвестиції в людський капітал - найефективнішими. Зміна підходів до розуміння і визнання соціально-економічного поступу сучасного бізнесу у свою чергу вимагає розробки відповідних методичних вказівок щодо використання інструментарію всебічної та об'єктивної оцінки стану соціальних відносин і соціальної відповідальності на корпоративному рівні. Одним із таких інструментів є аудит, який допомагає виявити потенційні загрози соціальному клімату, розкрити резерви розвитку людського капіталу (Sotsialnyi audyt..., 2020). Зазвичай метою аудиту соціальної відповідальності $€$ вивчення існуючих ризиків у сфері соціальних відносин сучасного бізнесу, шляхи їхньої мінімізації, а також вивчення окремих явищ, які сприймаються персоналом як порушення законодавчих та етичних норм і створюють суттєві перешкоди у формуванні позитивного іміджу керівництва в очах співробітників (Hnatyshyn et al., 2020). Аудит соціальної відповідальності дозволить визначити причини спаду виробництва, скорочення зайнятості, зростання економічно неактивного населення i безробіття. Через відсутність розвинених альтернативних сфер прикладання праці на селі вивільнена робоча сила перейшла в особисте підсобне господарство, яке на першому етапі стало стримуючим фактором відкритого безробіття. Аудит також дозволить виявити гострі проблеми накопичилися в сфері підготовки кваліфікованих робітничих кадрів, адже господарства, які намагаються відновити кадровий потенціал на хвилі економічного підйому, зіткнулися з проблемою “нового дефіциту” кадрів, яка обумовлена надзвичайно низькою ціновою політикою на вироблену продукцію і відповідно оплатою праці в сільському господарстві.

Нині ефективне використання потенціалу аграрного сектору України заслуговує на особливу увагу, адже освоєння ринкової системи господарювання своєю невизначеністю впродовж тривалого періоду лише гальмує розвиток ринкових земельних відносин в інтересах селян та сільських громад, головною метою якого є становлення ефективного господаря на землі (Sabluk, 2020). Складність проблеми полягає в тому, що нині в сільському господарстві рівень заробітної плати один з найнижчих, умови праці і зайнятості не привабливі, а виробнича і соціальна інфраструктура недостатньо розвинена, що негативно впливає на процес залучення талановитих кадрів. В результаті, в даний час в АПК і сільському господарстві в основному працюють люди похилого віку, підлітки, жінки і частина чоловіків, які переважно не мають можливості і альтернативних варіантів працевлаштування в інших галузях економіки. В цілому, АПК і сільське господарство втратило привабливість 
для молоді, здатної підняти цю важливу галузь на рівень стабільного і стійкого розвитку.

Спостерігається суттєве збільшення чисельності працездатного населення, зайнятого виключно в особистому селянському господарстві. Праця в особистому селянському господарстві суттєво відрізняється від праці в суспільному виробництві. Основою взаємодії сільськогосподарського підприємства із особистим селянським господарством служить економічний інтерес. Як наслідок, чим вищою є дана взаємодія, тим більше буде у згаданих сторін спільних інтересів. Аграрне підприємство має сприяти розвитку селянського господарства 3 метою забезпечення для себе відтворення робочої сили. Інтереси селян, які працюють у селянському господарстві полягають у забезпеченні потреб сім’і та зростанні доходів, а інтерес будь-якого сільськогосподарського підприємства - у збільшенні прибутку.

Тому великі підприємства виробляють продукцію, яка потребує не надто значних витрат праці, а виробництво трудомісткої продукції залишається за особистими селянськими та фермерськими господарствами (Hindes, 2009). Зростаюча роль людських ресурсів в економіці інноваційного типу обумовлює комплексне переосмислення кадрової політики держави у всіх сферах діяльності відповідно до вимог нової економічної ситуації. Говорячи про умови нової економічної ситуації, необхідно виділити іiї основні риси, такі як динамізм виробничих процесів, зміни у середовищі бізнесу, нестійкість попиту і пропозиції на ринку, обмеженість ресурсів, політика подвійних стандартів основних гравців ринку тощо, що в сукупності не залишає іншого вибору ніж адаптація всіх механізмів і систем функціонування національної економіки до нових ii викликів. В цьому відношенні слід констатувати і необхідність модернізації існуючих механізмів кадрового забезпечення аграрного сектору національної економіки.

На початкових стадіях реформ відзначалося, що ситуація вимагала, по-перше, визначити на селі власника землі, майна і результатів праці, по-друге, структуризувати на основі власності принципово нові виробничі відносини, які складаються із земельних, майнових і трудових відносин і, по-третє, на базі цього сформувати організаційно-правові структури ринкового типу, забезпечити утворення в сільському господарстві країни приватного сектору (Sabluk, 2001). Тим часом, проблеми підготовки та якості робочої сили, формування професійних компетенцій, перепідготовки та підвищення кваліфікації кадрів, формування конкурентоспроможності працівників в аграрному секторі АПК, як і в інших сферах економіки, нерозривно зв'язані з проблемою професійної орієнтації, що відбиває ступінь впливу чинників мотивації на поведінку людських ресурсів. По суті, кадрове забезпечення це один 3 аспектів концепції мотивації кадрів, яка в кожній групі працівників, в залежності від специфіки галузі та території, обумовлює застосування конкретних важелів впливу, з метою стимулювання працівників на ефективну трудову діяльність і службову кар'єру в рамках обраної професії. Руйнування системи професійної освіти призве- ло до того, що на ринку праці ускладнює працевлаштування молоді навіть при наявності вакансій. Регулювання сільського ринку праці є процесом організації та контролю його функціонування новоствореними ОТГ (об'єднаними територіальними громадами), що передбачає збалансування попиту і пропозиції робочої сили, поліпшення умов зайнятості в аграрній та інших сферах сільської економіки, гнучке управління відтворенням робочої сили через системи ії підготовки, перепідготовки і використання.

Слід зазначити, що розгляд поточного етапу ринкових трансформацій обов'язково слід здійснювати узгоджено із кроками у процесі євроінтеграції України. Для України важливим є здійснення співробітництва у сферах щодо забезпечення гідної праці, політики зайнятості, безпечних та здорових умов праці, соціального діалогу, соціального захисту, соціального залучення, гендерної рівності та недискримінації. Про це, зокрема, свідчить положення ст. 424 Угоди про інтеграцію "Україна забезпечує поступове наближення до права, стандартів та практики СС у сфері зайнятості, соціальної політики та рівних можливостей”. Норми цієї угоди мають бути застосовані й до регулювання ринку праці в сільській місцевості (Pivtorak, 2019). Основними напрямками реалізації кадрової політики повинні бути: формування єдиного освітнього комплексу АПК з урахуванням гнучкості всіх форм навчання; здійснення поетапного переходу на багаторівневу структуру вищої, передвищої, середньої i початкової освіти; організація масової підготовки і перепідготовки керівників підприємств, підрозділів, фахівців і фермерів; вдосконалення системи підготовки та перепідготовки кваліфікованих робітників; відмова від вузькопрофесійного орієнтації навчальних закладів. Також слід встановити квоти на цільову підготовку фахівців для агропромислового комплексу у вищих навчальних закладах. Цільові направлення повинні видаватися випускникам сільських шкіл безпосередньо сільськогосподарськими підприємствами, або новоствореними ОТГ.

Україна на порозі ключових перетворень в агросекторі і земельних правовідносинах. За останні два роки в агросекторі було реалізовано більше базових змін, чим за останні 10 років в країні. Мова про скасування мораторію на обіг земель сільськогосподарського призначення, законів щодо дерегуляції, сільськогосподарської кооперації, запуск порталу геопросторових даних. Реалізація реформи відбуватиметься поетапно із конкурентними правилами на умовах, що сприятимуть розвитку аграрного виробництва та сільських територій. 32021 до 2024 року право на купівлю землі буде тільки у громадян України. Також ключовою складовою ефективного розвитку вітчизняного агросектору $є$ прийнята Стратегія-2030. Основний акцент в ній робиться на малого і середнього сільськогосподарського товаровиробника, формування доданої вартості на кожному етапі виробництва сільськогосподарської продукції, максимальну цифровізацію процесів, залучення максимальної кількості agroteh рішень, які дадуть можливість мінімізувати вплив чиновників на будь-які процеси в агросекторі (Roman Leshchenko..., 2021). Соціальні фактори володіють 
значними можливостями активного впливу на результати виробництва. Перетворення умов життя людей, розвиток всієї соціальної сфери створюють загальну сприятливу психологічну ситуацію для продуктивної праці. Однак це вимагає значних капітальних вкладень держави, а також власних коштів сільськогосподарських підприємств. У реальної макроекономічної ситуації різко звужуються можливості використання цього фактору в підвищенні ефективності аграрного виробництва і всього агропромислового комплексу. Метою формування соціально-економічної політики держави в аграрній сфері на рівні національної економіки $\epsilon$ задоволення все зростаючих суспільних потреб, досягнення певного рівня життя населення, створення необхідних економічних, соціальних і екологічних умов для ефективного розвитку економіки i життєдіяльності людини. Ступінь задоволення соціально-економічних потреб в суспільстві залежить від конкретного змісту проведеної державою соціальноекономічної політики. Раціональне використання трудових ресурсів виступає одним 3 резервів підвищення ефективності агропромислового комплексу. Соціально-економічна політики держави в аграрній сфері повинна забезпечувати перш за все, зростання ефективності агропромислового виробництва, підтримку всіх форм підприємництва, організаційноінституційні та структурні перетворення 3 метою практичного подолання інерції і обмежень в процесі пристосування економічних суб'єктів до вимог ринкової економіки.

\section{Висновки}

Аналіз проблем розвитку соціально-трудових відносин в аграрному секторі АПК показав, що в ході здійснення трансформаційних процесів основну увагу приділяють приватизації, реструктуризації, оподаткуванню, залишаючи на потім вирішення проблеми соціально-трудової сфери. Прорахунки в соціальноекономічній політиці обертаються негативними наслідками і втратою людського капіталу. Одна з особливостей періоду інтеграції України з СС в Україні полягає в тому, що держава не регламентує змісту соціально-трудових відносин, а інші регулятори, такі як соціальне партнерство ще не працюють на повну потужність. Найбільш серйозні проблеми були в соціально-трудових відносинах безпосередньо на сільгосппідприємствах і особливо у фермерських та господарствах населення. Необхідний ефективний державний вплив, використовуючи можливості ОТГ, аудит соціальної відповідальності на формування національної моделі соціально-трудових відносин та ефективного використання трудового потенціалу.

Перспективи подальших досліджень. Подальший розвиток соціально-трудових відносин повинен здійснюватись в контексті інтеграції України з СС, що висуває необхідність вдосконалення соціальноекономічної політики щодо аграрного сектора в умовах іiі трансформації і пристосування до інтеграційних структур Свропи. Доцільно визначити основні напрямки і пріоритети соціально-економічної модернізації ОТГ в найближчі роки. Головними з них $є$ : просвіта та популяризація знань, в тому числі реформа сільських профтехучилищ, пошук нових форм навчання дорослих, розвиток економічної, технічної та соціальної інфраструктури, підтримка підприємництва і несільськогосподарської діяльності в сільській місцевості.

\section{References}

Kolot, A. M., \& Herasymenko, O. O. (2019). Sotsialnotrudovyi rozvytok u XXI stolitti: do pryrody hlobalnykh zmin, novykh mozhlyvostei, obmezhen i vyklykiv. Demohrafiia ta sotsialna ekonomika, 1(35), 97-125. doi: 10.15407/dse2019.01.100 (in Ukrainian).

Hrishnova, O. A. (2011). Sotsialna vidpovidalnist u konteksti podolannia systemnoi kryzy v Ukrayini. Demohrafiia ta sotsialna ekonomika, 1(15), 39-46 doi: 10.15407/dse2011.01.039 (in Ukrainian).

Hnatyshyn, L., Kostyrko, I., Prokopyshyn, O., \& Maletska, O. (2020). Audyt sotsialnoi vidpovidalnosti biznesu. Visnyk Lvivskoho natsionalnoho ahrar-noho universytetu: ekonomika APK, 27, 178-183. URL: http://visnuk.kl.com.ua/joom/images/archive/econ/27_ 2020/Econ-27-2020-33.pdf (in Ukrainian).

Sotsialnyi audyt: sutnist, zmist, vydy. URL: https://stud.com.ua/61866/sotsiologiya/sotsialniy_audi t_sutnist_zmist_vidi (data zvernennia: 15.05.2020) (in Ukrainian).

Sabluk, P. T. (2020). Nevidkladni zakhody dlia vrakhuvannia pry zaprovadzhenni rynkovykh zemelnykh vidnosyn. Ekonomika APK, 2, 126-134. doi: 10.32317/2221-1055.202002126 (in Ukrainian).

Tkachuk, V. A. (2019). Suchasnyi stan i tendentsii rozvytku ahrarnoho rynku pratsi. Ekonomika APK, 7, 6-13. doi: 10.32317/2221-1055.201907006 (in Ukrainian).

Serednii riven zarplat u silskomu hospodarstvi vid sichnia do lypnia zris na 1 tys. hrn. URL: https://agropolit.com/news/17393-seredniy-riven-zarplatu-silskomu-gospodarstvi-vid-sichnya-do-lipnya-zris-na1-tis-grn (data zvernennia: 10.09.2021) (in Ukrainian).

Hindes, O. H. (2009). Realizatsiia sotsialnoho napriamu ah-rarnoi polityky. Elektronnyi zhurnal. Derzhavne upravlinnia: udoskonalennia ta rozvytok, 1, URL: http://www.dy.nayka.com.ua/?op=1\&z=6 (data zvernennia: 10.09.2021) (in Ukrainian).

Sabluk, P. T. (2001). Nova ekonomichna paradyhma formuvannia stratehii ratsionalnoi prodovolchoi bezpeky u KhKhI stolitti. Ekonomika APK, 4, 13-19 (in Ukrainian).

Pivtorak, A. (2019). Instytutsiini zasady orhanizatsiinoekonomichnoho mekhanizmu rehuliuvannia rynku pratsi v Ukraini u silskii mistsevosti. Visnyk Akademii pratsi, sotsialnykh vidnosyn i turyzmu, 3, 85-95. doi:10.33287/11215 (in Ukrainian).

Mistse Ukrainy u svitovomu ahrarnomu eksporti. URL: https://agroter.com.ua/2021/03/20/infografika-misczeukrayiny-u-svitovomu-agrarnomu-eksporti/\# (data zvernennia: 10.09.2021) (in Ukrainian).

Roman Leshchenko nazvav kliuchovi reformy $\mathrm{v}$ ahrosektori. URL: https://agropolit.com/news/20059roman-leschenko-nazvav-klyuchovi-reformi-vagrosektori (data zvernennia: 10.09.2021) (in Ukrainian). 